\title{
Developing Denim Like Wash Effect on Corduroy Garments and Investigation of Different Physical Properties of Washed Corduroy Garments
}

\author{
Gazi Farhan Ishraque Toki1 , Akash Banik1, Taosif Ahmed1,2* (D), Rony Mia1,3 (D), \\ Rezaul Karim Khan Alave', Jarin Jahan', Md. Mostafizur Rahman Palash ${ }^{4}$, Md. Salman Farsee ${ }^{3}$ \\ ${ }^{1}$ Department of Textile Engineering, National Institute of Textile Engineering \& Research (NITER), Savar, Dhaka, Bangladesh \\ ${ }^{2}$ School of Environmental Engineering, Wuhan Textile University, Wuhan, China \\ ${ }^{3}$ College of Chemistry \& Chemical Engineering, Wuhan Textile University, Wuhan, China \\ ${ }^{4}$ School of Technical Research, Wuhan Textile University, Wuhan, China \\ ${ }^{5}$ Department of Textile Engineering, Pabna Textile Engineering College (PTEC), Shalgaria, Pabna, Bangladesh \\ Email: *taosif.ahmed@outlook.com
}

How to cite this paper: Toki, G.F.I., Banik, A., Ahmed, T., Mia, R., Alave, R.K.K., Jahan, J., Palash, Md.M.R. and Farsee, Md.S. (2021) Developing Denim Like Wash Effect on Corduroy Garments and Investigation of Different Physical Properties of Washed Corduroy Garments. Journal of Textile Science and Technology, 7, 1-13. https://doi.org/10.4236/jtst.2021.71001

Received: December 19, 2020

Accepted: January 19, 2021

Published: January 22, 2021

Copyright $\odot 2021$ by author(s) and Scientific Research Publishing Inc. This work is licensed under the Creative Commons Attribution International License (CC BY 4.0).

http://creativecommons.org/licenses/by/4.0/

(c) (i) Open Access

\begin{abstract}
Corduroy yarn is generally introduced in a fabric structure of garments due to developing different designs in terms of appearance of fabric which is called corduroy garment. In this study, both corduroy and denim garments have been made to develop a denim-like wash effect on corduroy garments that will create a new fashion, value addition and sustainability in washing technology. Both the garments are treated with the same washing process. Also, some physical properties have been investigated for both washed garments such as Washing Effect Test, Tear Strength Test, GSM Test, and Rubbing Test. Then a comparative study has been done on both washed garments. The appearance of washed corduroy garments is satisfactory. The physical properties also show a better result. Finally, a satisfactory result is achieved from this work.
\end{abstract}

\section{Keywords}

Washing and Finishing Treatments, Denim, Corduroy, Rubbing Test, Tearing Strength, Gram Per Square Meter Test

\section{Introduction}

In recent times, garments washing has improved highly in Bangladesh. It is one of the major processes followed in the textile sector. By garments washing, dust, 
dirt and infectious materials can be removed from garments. For improving the special look on garments as per fashion requirements, a variety of wash techniques can be followed. Washing will be substantially helpful for making enough headway in the RMG sector [1] [2]. Day by day, the demand for washed garments is increasing more. Most of the time we use to wash denim garments. Because denim fabric is dyed with vat dye and it can easily be faded by some process. But if we use wash effect on other types of fabric it can make a result that the goal we are going for. In here we will see the wash effect on corduroy garments.

The dominance of corduroy garments broke down in the early 19th century. But from the last year 2017, the curse that was bestowed on corduroy garments has officially broken [3] [4]. By the Rob Report, 2017, the dominance of corduroy garments has proliferated runways from Paris, New York, and Milan [5]. But in Bangladesh, there is a lack behind the development of corduroy garments or the use of this garment. Since Bangladesh has a lack of fashion development, so there is a need to develop the fashion site wherever it is possible [6] [7]. We choose to do denim-like washing treatment on corduroy garments to bring a new look to corduroy garments.

Corduroy is not as popular as denim in our country, but its popularity or look can be enhanced through some ways such as washing. Corduroy garments did not run through denim like the washing process before, except normal wash and normal enzyme wash. So, there is a huge space to develop a wash effect on corduroy garments [8] [9]. The main purpose of this thesis is to bring some selected washing effect on corduroy garments and compare with washed denim garments through some physical test. Mainly this thesis work is focused on the open of a new page on the fashion site and washing site through the development of corduroy garments.

\section{Research Questions, Objectives}

The main research question of this study is "Is it possible to achieve denim like wash effect using corduroy garments"? So, in terms of research questions the primary objective is:

$>$ To develop different denim like wash effect on corduroy garments.

> To investigate physical properties of both denim and corduroy garments.

$>$ To do a comparative study and finally develop a compare between washed denim and corduroy.

\section{Experimental Details}

\subsection{Materials}

The chemicals, amylase enzyme, potassium permanganate, sodium meta bisulfate, softener, acetic acid, used for washing purposes were obtained from an Indian supplier (Mark Indian) and were used without further purification. Commercially available corduroy and denim fabrics were purchased from a local market (Bangladesh) for washing. The construction of corduroy and denim fabric is given below. 


\section{Corduroy:}

Construction: $18 \times 20+70 \mathrm{D} / 65 \times 60$ Weave: Cord;

Com position: $97 \%$ Cotton 3\% Spandex.

Denim:

Construction: $40 / 2 \times(170 \mathrm{D}+40 \mathrm{D}) / 145 \times 74$ Weave: $4 / 1$ Satin;

Composition: $65 \%$ Cotton, $33 \%$ poly, $2 \%$ Spandex.

\subsection{Methodology}

Firstly, we have collected denim \& corduroy fabric from the local market. After that, we made the pattern, cut, sew, and made the final garments. When we got the Final garments for denim \& corduroy, then we were going for the washing process. We did several washing methods like Towel bleach, all over PP, Dip Bleach, Acid wash, stone wash, etc., and were checked all washing parameters and fashion looks. Then we used the testing method to determine Tear strength, GSM testing \& Colorfastness to rubbing properties and compared the results between denim \& Corduroy (Figure 1).

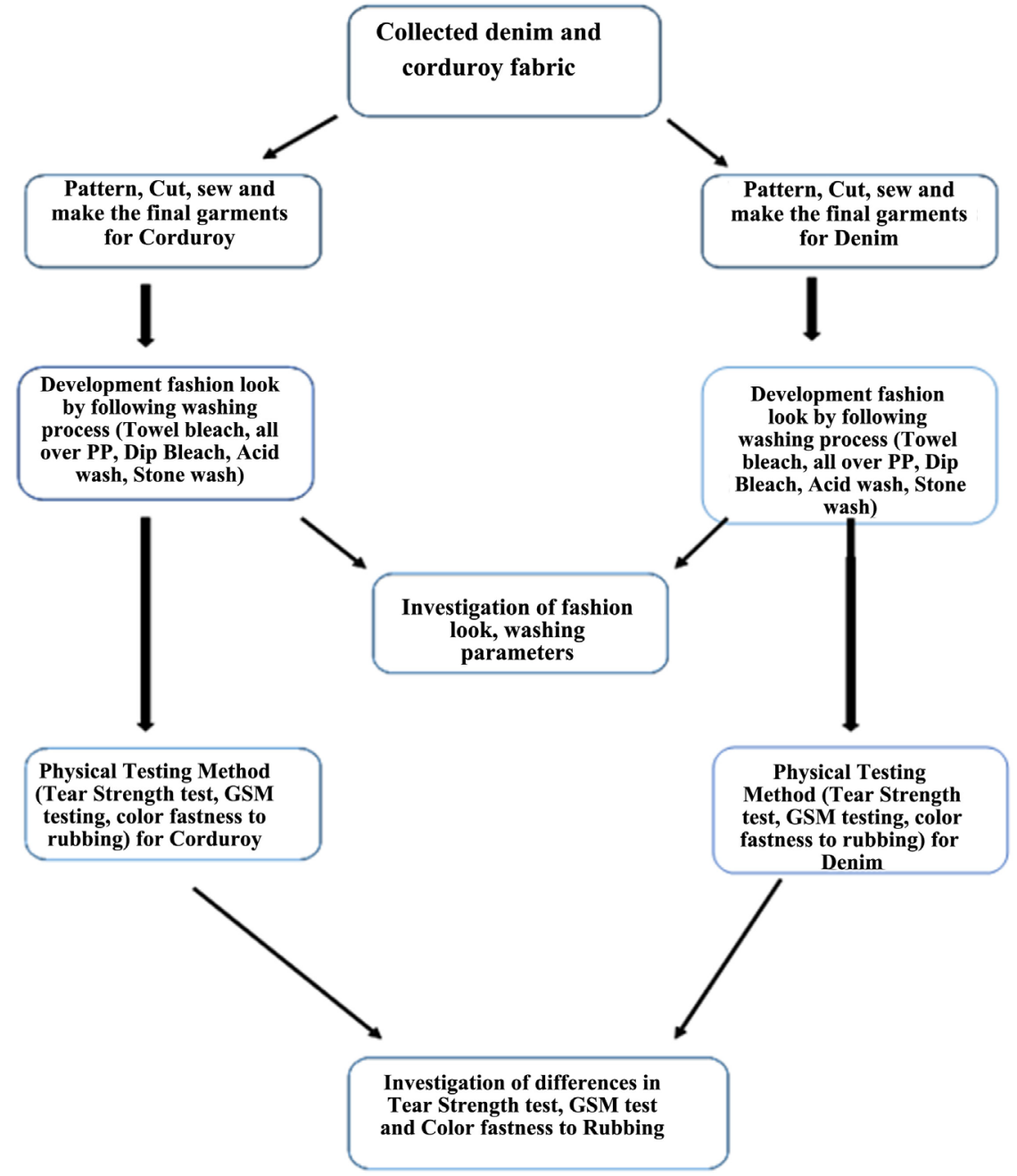

Figure 1. Schematic illustration of research design. 


\subsection{Treatment Procedure}

Two samples were prepared as long pant which had 35" waist, 15" Hip, 23" Thigh and 18" Tubular bottom width. There were a total 12 long pant samples prepared for this experiment [10] [11]. Table 1 shows the washing treatment, treatment condition and the duration condition for Denim \& Corduroy fabrics.

\subsection{Testing Procedure}

\section{Tear Strength Test}

Both cord and denim fabric were taken. Warp and weft direction of the fabric in both directions have the dimension of $100 \times 63 \mathrm{~mm}$. The sample was fixed in the jaws of the tearing tester. A cut of $20 \mathrm{~mm}$ was made along the width of the fabric using the cutter in the tearing tester [12] [13]. By using the falling pendulum of the tearing tester the fabric was a tear and the readings were noted from Elmendorf's testers scale. The same procedure was done for the different samples and the result was taken.

\section{GSM Test}

Cut 5 Swatches from the different places of the fabric. Weight all test swatches accurately and calculated the average weight of swatches. The average weight of the sample fabric was multiplied by 100 to calculate GSM [14] [15]. The same procedure was done for the different samples and the result was taken.

\section{Color Fastness Rubbing}

Table 1. Treatment procedure.

\begin{tabular}{|c|c|c|}
\hline Treatment & Condition & Time \\
\hline $\begin{array}{c}\text { Enzyme Wash } \\
\text { [Type-1] }\end{array}$ & $\begin{array}{c}\text { Temperature }=55^{\circ} \mathrm{C} \\
\text { Enzyme: Cellulose enzyme }(\mathrm{pH}=5) \text { for Denim } \\
\text { Neutral Enzyme for Corduroy }\end{array}$ & $\begin{array}{l}30 \mathrm{~min} ., 60 \mathrm{~min} . \\
\text { And } 90 \mathrm{~min} .\end{array}$ \\
\hline $\begin{array}{c}\text { Towel bleach }+ \text { PP } \\
\text { [Type-2] }\end{array}$ & $\begin{array}{c}\text { Temperature }=60^{\circ} \mathrm{C} \\
\text { Enzyme: Amylase enzyme } \\
\text { Neutral: Sodium met bisulfite }\left(\mathrm{Na}_{2} \mathrm{~S}_{2} \mathrm{O}_{2}\right)-2 \mathrm{gm} / \text { Liter } \\
\text { Acetic acid }-6 \mathrm{gm} / \text { Liter }\end{array}$ & $40 \mathrm{~min} ., 30 \mathrm{~min}$. \\
\hline $\begin{array}{c}\text { Enzyme }+ \text { Bleach }(\mathrm{KCI}) \\
{[\text { Type-3] }}\end{array}$ & $\begin{array}{c}\text { Bleach (KCI) - As required to get per shad } \\
\text { pH-Normal } \\
\text { Anti-back stain }-0.25 \mathrm{gm} \\
\text { Rinse: } 1 \text { or } 2 \text { times }\end{array}$ & $\begin{array}{l}30 \mathrm{~min} . \\
5 \mathrm{~min} .\end{array}$ \\
\hline $\begin{array}{l}\text { Enzyme }+ \text { Bleach } \\
\text { (Japanese) } \\
\text { [Type-4] }\end{array}$ & $\begin{array}{l}\text { Enzyme: Amylase enzyme } \\
\text { Rinse wash-1 time } \\
\text { Hydro Dryer }\end{array}$ & $\begin{array}{l}5 \mathrm{~min} . \\
10 \mathrm{~min} . \\
15 \mathrm{~min} .\end{array}$ \\
\hline $\begin{array}{c}\text { Towel bleach }+ \text { PP } \\
+ \text { Stone ball } \\
\text { [Type- } 5]\end{array}$ & $\begin{array}{c}\text { Temperature }=55^{\circ} \mathrm{C} \\
\text { Potassium permanganate }\left(\mathrm{KMnO}_{4}\right): 50 \mathrm{gm} / \mathrm{lit} \\
\text { Stone: New stones and worn-out stone } \\
1 \mathrm{~kg} \text { of stone for } 2 \text { samples }\end{array}$ & $30 \mathrm{~min} ., 60 \mathrm{~min}$. \\
\hline $\begin{array}{c}\text { Towel bleach }+\mathrm{PP}+\text { Cock } \\
\text { sheet pitch } \\
\text { [Type- } 6]\end{array}$ & $\begin{array}{c}\text { Temperature }=30^{\circ} \mathrm{C} \\
\text { Neutral: Sodium met bisulfite }-2 \mathrm{gm} / \text { Liter } \\
\text { Softener: } 2 \mathrm{gm} / \mathrm{lit} \\
\text { Cock sheet pitch: } 50 \text { pcs for } 2 \text { samples }\end{array}$ & $30 \mathrm{~min}$. \\
\hline
\end{tabular}


Place the test specimen lengthwise into the testing device make sure that the surface was not creased. If testing a multi-colored sample, making sure that the test specimen was positional in a way that all colors are rubbed during the test [16] [17] [18]. Place the rubbing cloth in the testing device. The warp or weft of the rubbing cloth should be perpendicular to the test direction. Rub ten times in an even place, approx., one cycle per second. Remove the rubbing cloth and specimen. After that, we followed the same procedure, but add one drop of water with the pipette to the rubbing cloth before placing it in the crock meter. Dry the rubbing cloth before evaluation.

\subsection{Limitations}

This thesis work has been done on only one color of the Corduroy garment. It can be done with other colors of Corduroy $\&$ the appearance can be tested. Due to the lack of lab facilities, only three types of test procedures are applied in this thesis. If other colors of Corduroy were used then the test result could be more fruitful. It would be beneficial for work if various information and measurement were got. It can be seen that time, facilities \& cost which play a superior role in work. If these terms get elongation, then more work and tests could be done which will help to gain knowledge of this Corduroy garment also useful for the textile industry.

\section{Results and Discussion}

\subsection{Washing Effect Test Results}

\subsubsection{Wash Effect on Corduroy Garments (Type-1: Enzyme Wash)}

In the corduroy garments wash effect of Enzyme, the result is satisfactory. The process developed denim-like wash as this wash was not applied before and also done without any damage in the corduroy garments. The main comparison between corduroy and denim is their color \& shade (Figure 2). Though the garments went through the same washing process, the effects of color \& shade are different. The hand feel of corduroy is better than denim.

\subsubsection{Wash Effect on Corduroy Garments (Type-2: Towel Bleach+ PP)}

The effect of towel bleach + PP wash on corduroy garment is satisfactory. The process gave fashionable and denim-like wash in corduroy. The difference between corduroy \& denim is color. After wash, the corduroy garment is lighter compared to denim. The corduroy is a light color with some shade on the whole garment but the denim is darker with a light shade in the middle of the garment. The hand feel of denim is smoother than corduroy (Figure 3).

\subsubsection{Wash Effect on Corduroy Garments (Type-3: Enzyme + Bleach (KCI))} The wash effect developed a fashionable look on corduroy garments. The wash effect did not damage the garment, which gives satisfaction in the work. The corduroy garment is a pinkish color with a lighter shade (Figure 4). And the denim garment is a silver color with a light shade. Comparing in shade, corduroy is lighter than denim. The hand feel of denim is better than corduroy. 


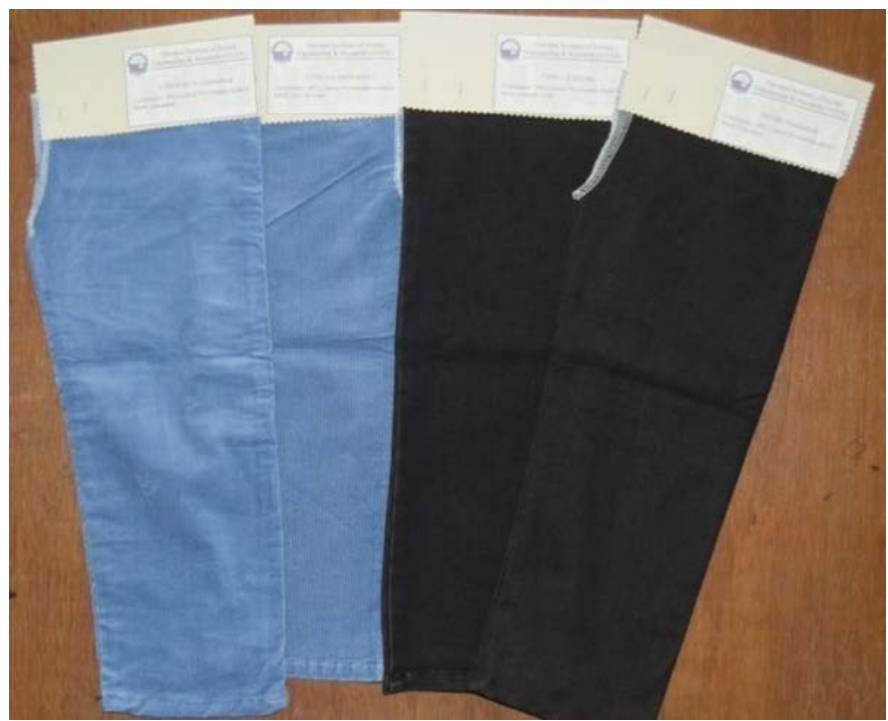

Figure 2. Wash effect on corduroy garments (Type-1: Enzyme Wash).

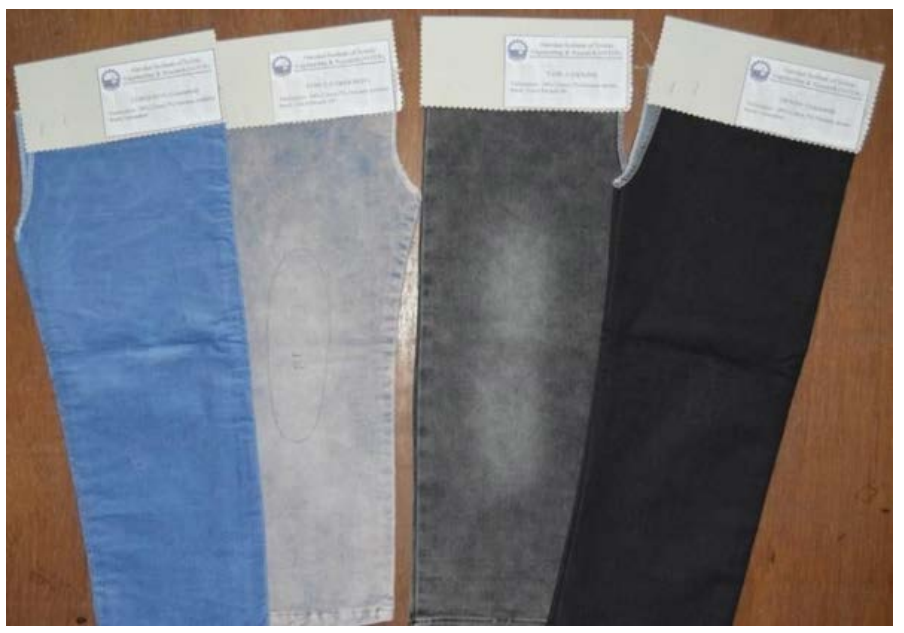

Figure 3. Wash effect on corduroy garments (Type-2: Towel bleach + PP).

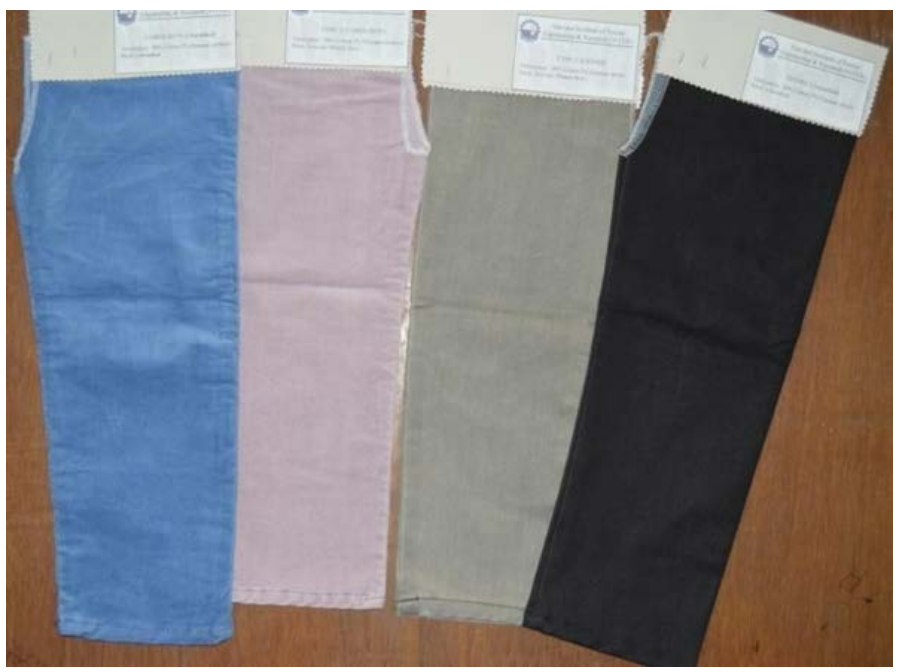

Figure 4. Wash effect on corduroy garments (Type-3: Enzyme + Bleach (KCI)). 


\subsubsection{Wash effect on Corduroy Garments (Type-4: Enzyme + Bleach (Japanese))}

The effect on the corduroy garment is a denim-like wash with a fashionable look that satisfies the work. Corduroy is a lighter shade with different color comparing to denim (Figure 5). The denim is deep in color on the whole garment. The hand feel of corduroy is not as good as denim.

\subsubsection{Wash Effect on Corduroy Garments (Type-5: Towel Bleach + PP + Stone Ball)}

The wash effect on corduroy is satisfactory which, got a denim-like wash and look without any damage. The corduroy has a bluish color with a fade look where the denim is black with a light shade in the middle of the garment (Figure 6). The smoothness of denim is better than corduroy.

\subsubsection{Wash Effect on Corduroy Garments (Type-6: Towel Bleach + PP + Cock Sheet Pitch)}

The wash effect of the corduroy garment is satisfactory. The garment has a fashionable and denim wash look. Denim has a better hand feel comparing to

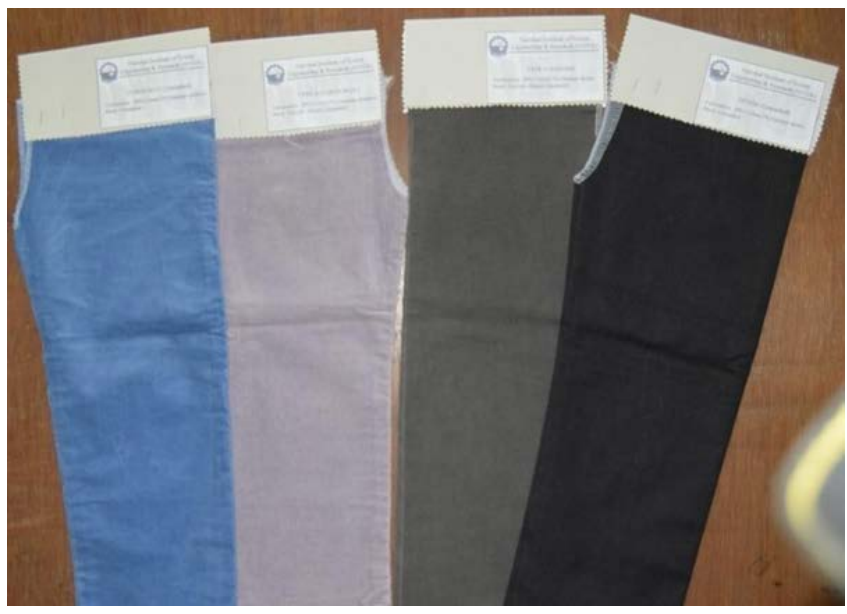

Figure 5. Wash effect on corduroy garments (Type-4: Enzyme + Bleach (Japanese)).

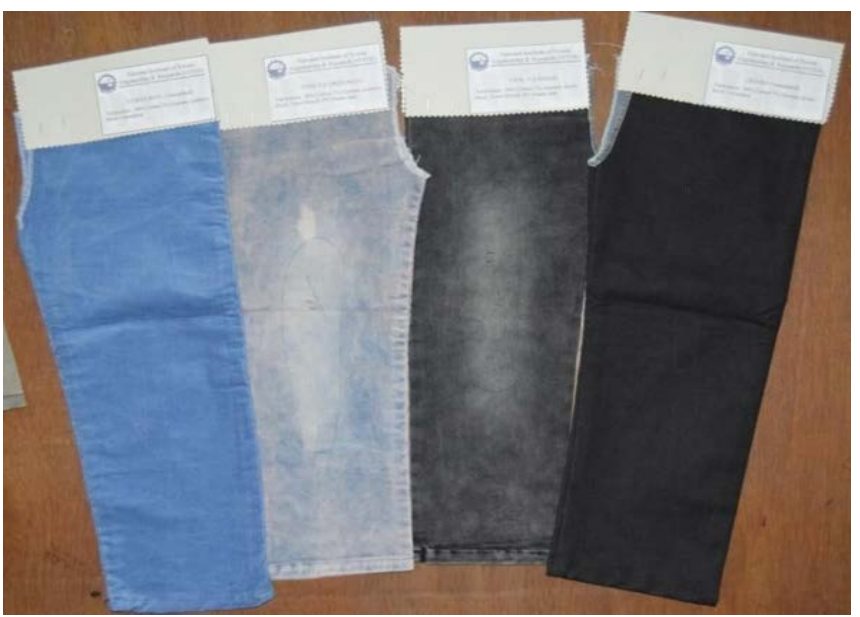

Figure 6. Wash effect on corduroy garments (Type-5: Towel bleach + PP + Stone ball). 
corduroy garments. Corduroy garment has fade bluish and light shade where the denim has black color and fade in the middle (Figure 7).

\subsection{Tear Strength Test Result}

The Tear Strength Test is done after various washing effects on garments (Table 2). Elmendorf s method is used in the test. This test is applied to both Corduroy and Denim garments. The result is satisfactory as this test gave corduroy a new idea to compete with denim garments.

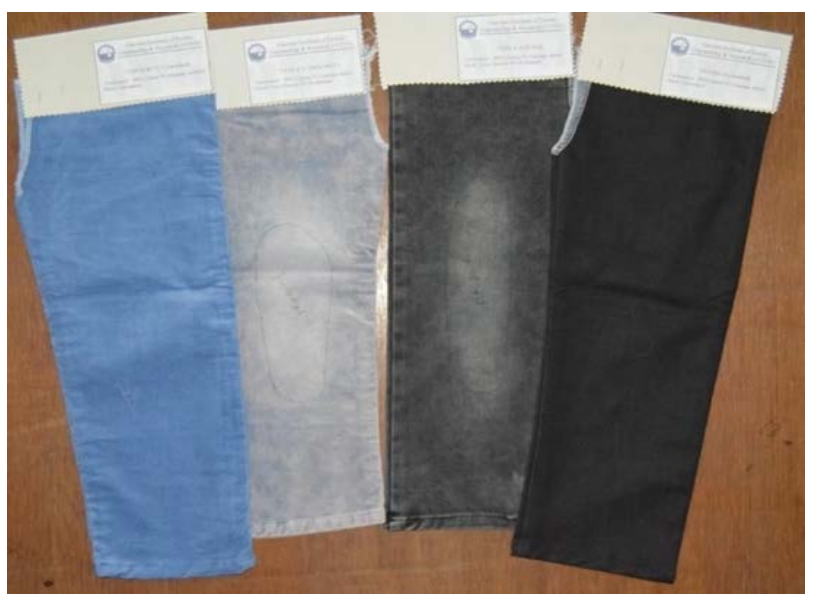

Figure 7. Wash effect on corduroy garments (Type-6: Towel + PP + Cock sheet pitch).

Table 2. Test results of tear strength.

\begin{tabular}{|c|c|c|c|}
\hline \multirow{3}{*}{$\begin{array}{l}\text { Washing } \\
\text { Process No. }\end{array}$} & \multirow{3}{*}{$\begin{array}{c}\text { Washing } \\
\text { Process Type }\end{array}$} & Denim & Corduroy \\
\hline & & $\begin{array}{l}\text { Write here "Warp" and correct } \\
\text { this table accordingly }\end{array}$ & $\begin{array}{l}\text { Write here "Weft" and correct } \\
\text { this table accordingly }\end{array}$ \\
\hline & & gm & gm \\
\hline \multirow{2}{*}{1} & \multirow{2}{*}{ Unwashed } & Warp: 5515 & Warp: 5037 \\
\hline & & Weft: 5073 & Weft: 5285 \\
\hline \multirow{2}{*}{2} & \multirow{2}{*}{ Type-1 } & Warp: 5898 & Warp: 5215 \\
\hline & & Weft: 6571 & Weft: 4655 \\
\hline \multirow{2}{*}{3} & \multirow{2}{*}{ Type-2 } & Warp: 3704 & Warp: 5787 \\
\hline & & Weft: 6677 & Weft: 5419 \\
\hline \multirow{2}{*}{4} & \multirow{2}{*}{ Type-3 } & Warp: 4283 & Warp: 5145 \\
\hline & & Weft: 5640 & Weft: 5319 \\
\hline \multirow{2}{*}{5} & \multirow{2}{*}{ Type-4 } & Warp: 5978 & Warp: 5285 \\
\hline & & Weft: 4154 & Weft: 4926 \\
\hline \multirow{2}{*}{6} & \multirow{2}{*}{ Type-5 } & Warp: 5925 & Warp: 5073 \\
\hline & & Weft: 4734 & Weft: 5578 \\
\hline \multirow{2}{*}{7} & \multirow{2}{*}{ Type-6 } & Warp: 5871 & Warp: 5215 \\
\hline & & Weft: 4368 & Weft: 4655 \\
\hline
\end{tabular}


In Tear Strength Test, corduroys highest point is in warp-5787 gm (type-2), weft-5578 gm (type-5) and lowest in warp-5037 gm (unwashed), weft-4655 gm (type-1, 6) where highest of denim in warp-5978 gm (type-4), weft-6677 gm (type-2) \& lowest in warp-3704 gm (type-2), weft-4154 gm (type-4). Denim has higher tear strength than corduroy because the more GSM the more Tear Strength (Figure 8, Figure 9).

\subsection{GSM Test Result}

GSM test is a measurement of Grams per Square Meter. GSM provides the weight per unit area or the weight per unit length. After washing effects on garments,

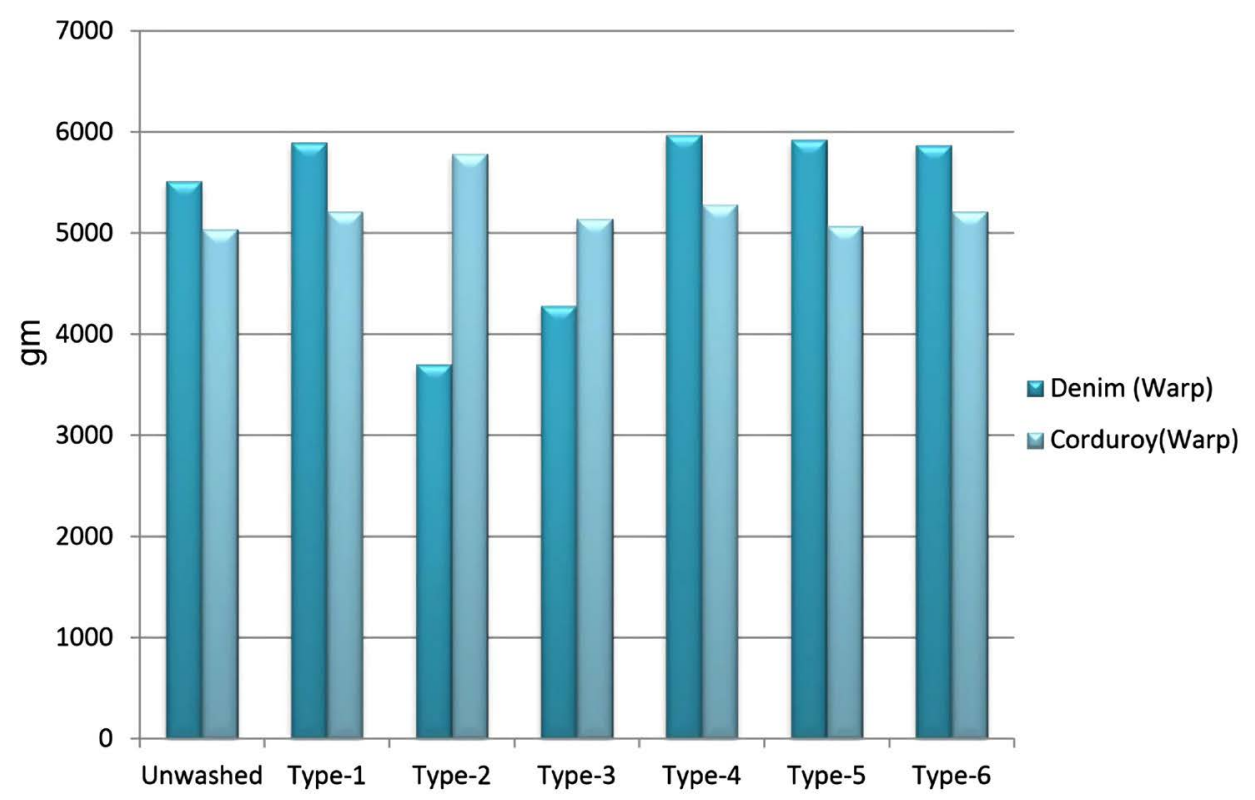

Figure 8. Tear strength test result (Warp way).

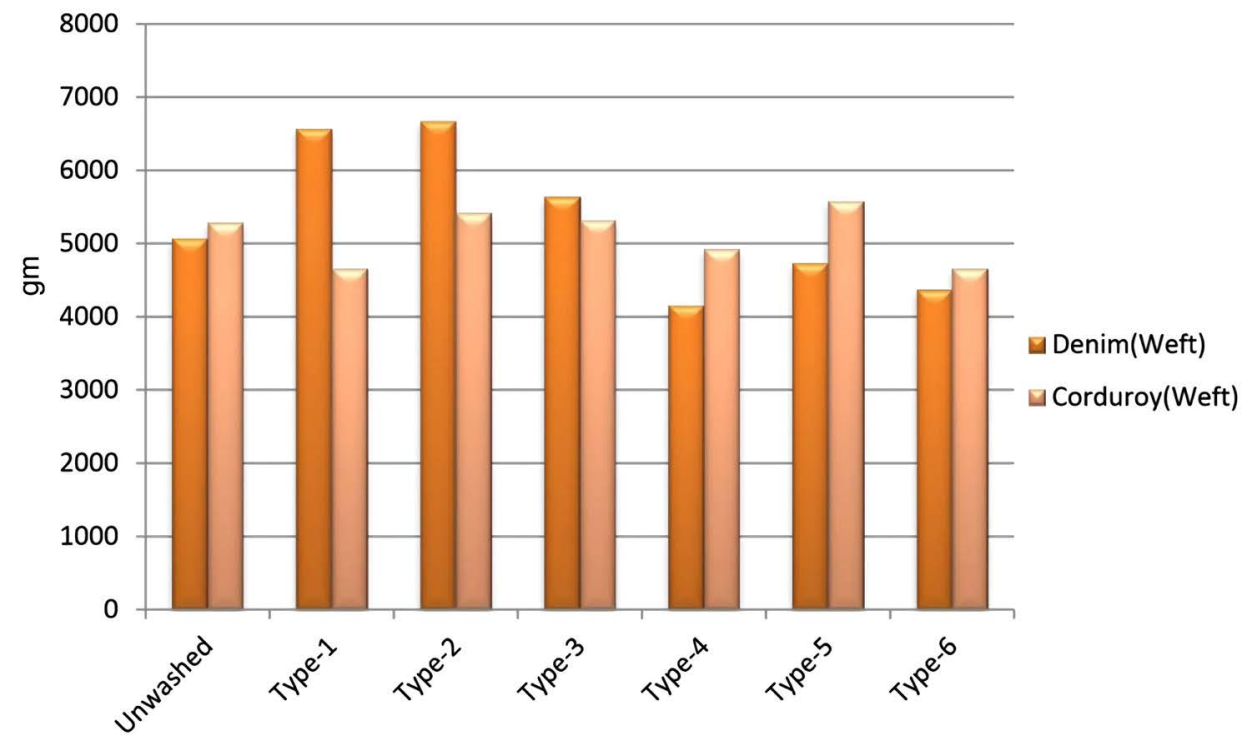

Figure 9. Tear strength test result (Weft way). 
the GSM test is done in both corduroy and denim garment (Table 3, Figure 10). The highest GSM is 300.607 gm (type-1) and the lowest GSM is 268.863 (type-3) gm in corduroy. Corduroy garments weight in type-1, type-3, and type- 4 is higher than denim garments. In denim, 314.07 gm (type-2) is the highest and 236.189 gm (type-3) is the lowest in the GSM test.

\subsection{Test Result of Color Fastness to Rubbing}

The Rubbing Test is done in corduroy and denim garments to determine the quality of the colored fabric (Table 4). This test measured in dry \& wet form with greyscale and staining scale. In this test, corduroy is comparatively better than denim in both dry and wet form (Figure 11, Figure 12). It can be seen that $4 / 5 \mathrm{~s}$ in corduroy garment is highest in all wash types. In denim, dry form is good but in wet form like 2, 2/3 which shows low colorfastness.

Table 3. GSM test results.

\begin{tabular}{cccccc}
\hline \multirow{2}{*}{ Washing Process No. } & Washing Process Type & \multicolumn{2}{c}{ Denim } & \multicolumn{2}{c}{ Corduroy } \\
\cline { 3 - 6 } & & gm & oz & gm & oz \\
\hline 1 & Unwashed & 294.81 & 8.65 & 288.3 & 8.50 \\
2 & Type-1 & 270.3 & 7.98 & 300.607 & 8.86 \\
3 & Type-2 & 314.07 & 9.26 & 290.439 & 8.57 \\
4 & Type-3 & 236.189 & 6.97 & 268.863 & 7.93 \\
6 & Type-4 & 263.624 & 7.78 & 271.235 & 8.00 \\
7 & Type-5 & 301.4 & 8.89 & 300 & 8.85 \\
\hline
\end{tabular}

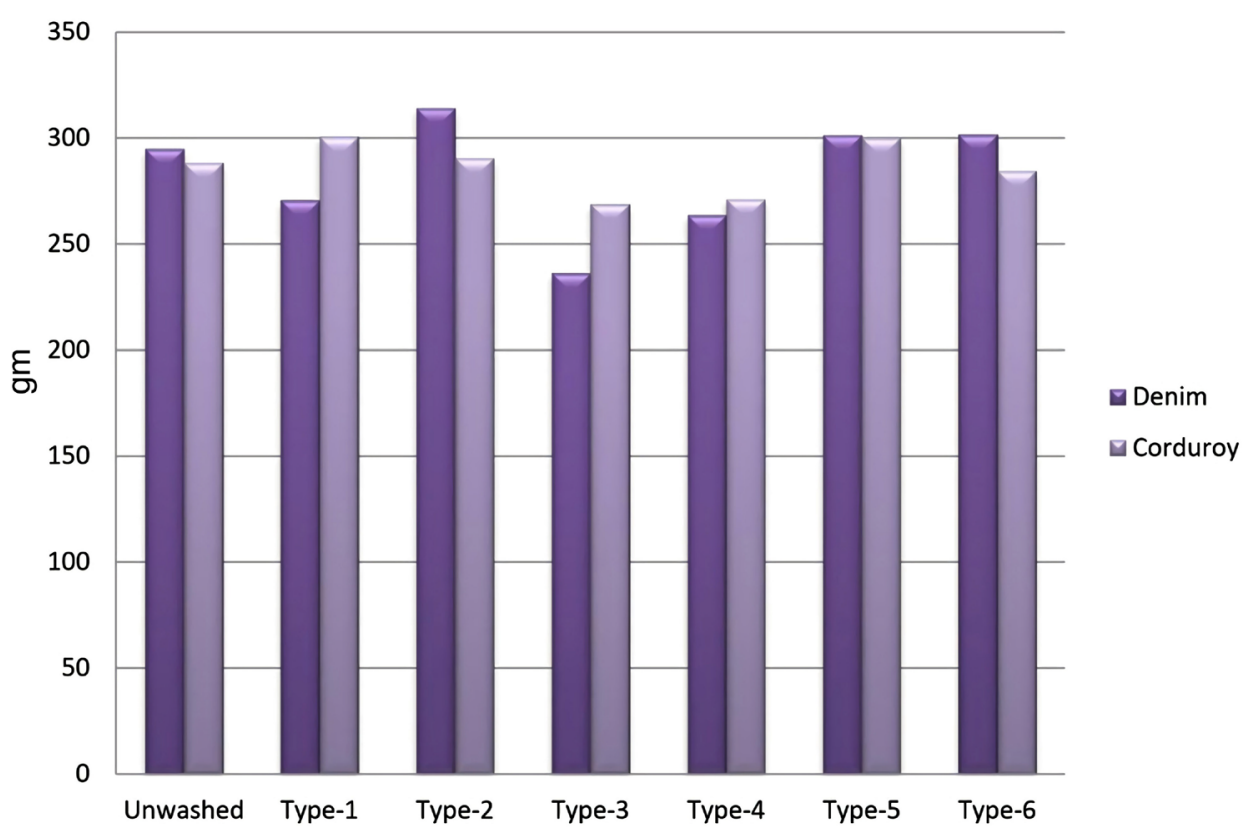

Figure 10. GSM Test of Denim \& Corduroy after washing process. 
G. F. I. Toki et al.

Table 4. Test results of tear strength color fastness to rubbing.

\begin{tabular}{cccccc}
\hline \multirow{2}{*}{ Washing Process No. } & \multirow{2}{*}{ Washing Process Type } & \multicolumn{2}{c}{ Denim } & \multicolumn{2}{c}{ Corduroy } \\
\cline { 3 - 6 } & & Dry (S) & Wet (S) & Dry (S) & Wet (S) \\
\hline 1 & Unwashed & $4 / 5$ & 2 & $4 / 5$ & $4 / 5$ \\
2 & Type-1 & $4 / 5$ & $2 / 3$ & $4 / 5$ & $4 / 5$ \\
3 & Type-2 & 4 & $2 / 3$ & $4 / 5$ & $4 / 5$ \\
4 & Type-3 & $4 / 5$ & $4 / 5$ & $4 / 5$ & $4 / 5$ \\
5 & Type-4 & $4 / 5$ & $2-3$ & $4 / 5$ & $4 / 5$ \\
6 & Type-5 & 4 & 2 & $4 / 5$ & $4 / 5$ \\
7 & Type-6 & $3 / 4$ & 2 & $4 / 5$ & $4 / 5$ \\
\hline
\end{tabular}

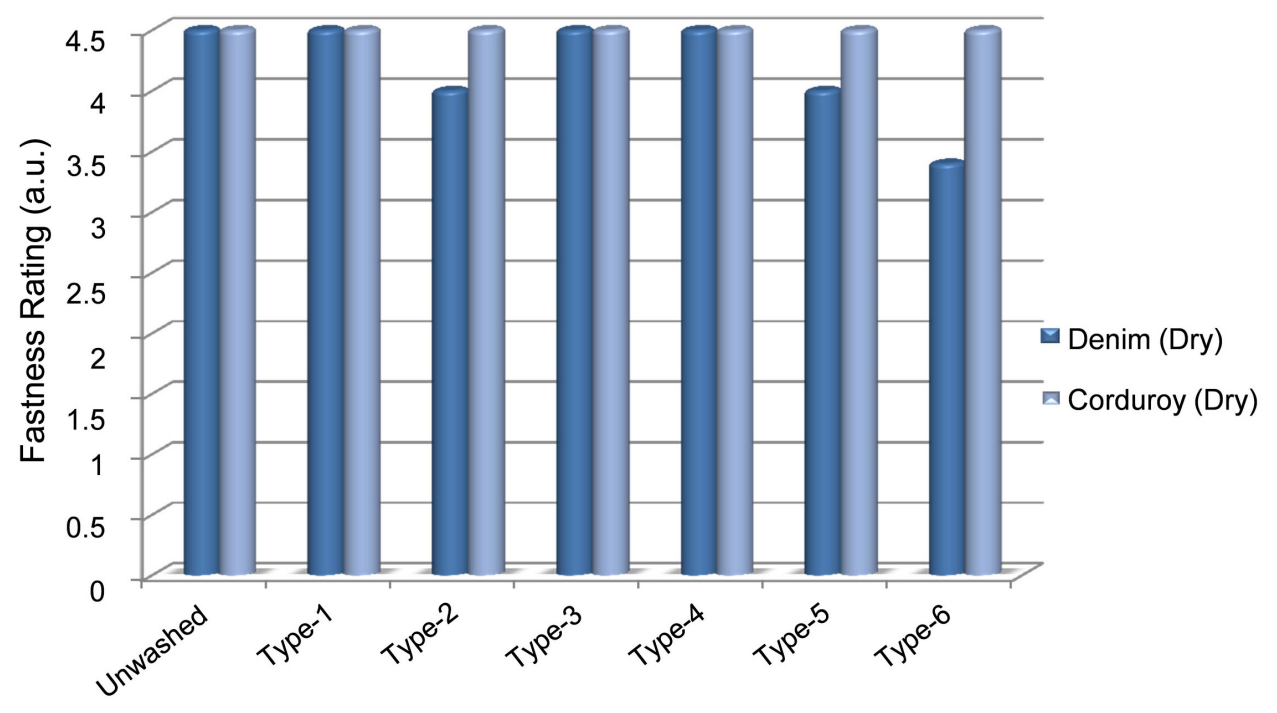

Figure 11. Color fastness to rubbing test result (Dry Form).

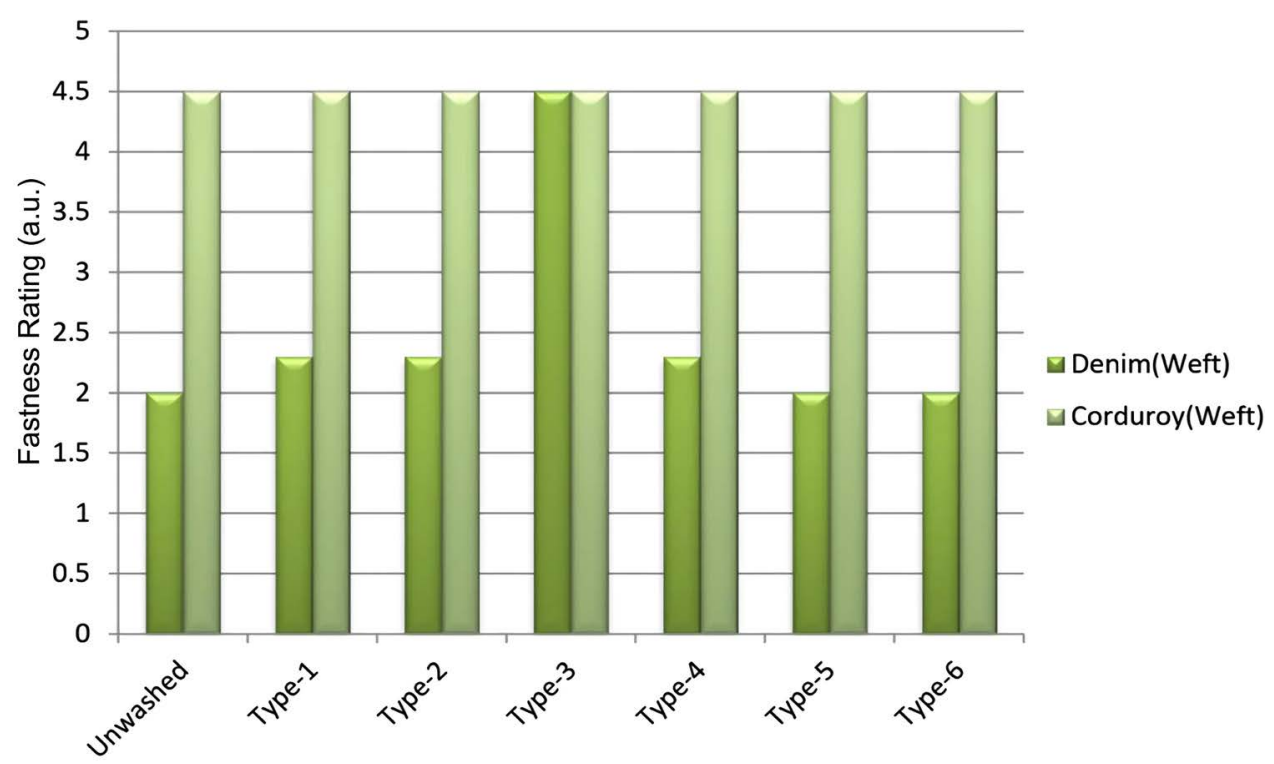

Figure 12. Color fastness to rubbing test result (Wet Form). 


\section{Conclusions}

Corduroy and Denim garments are fundamentally different fabrics. It comes to variety in washes, denim has more style options than its corduroy counterpart [19] [20]. The main reason for this thesis was to get various washing effects and investigate different physical properties in corduroy garments. There were four experiments on garments during this paperwork, these were washing effects test, the GSM test, the tear strength test, the rubbing test and the washing effect test.

According to the research, the work is perfectly done with limited time and the results bring satisfaction. In this study, the corduroy garments got a denimlike wash and comparable to denim garments. The wash effects of corduroy are new and fashionable. The colour and shade between corduroy and denim are different in each wash type. In the GSM Test, denim is highest in wash type-6 (301.44 gm) and corduroy is highest in wash type-1 (300.607 gm), where denim is better but corduroy is compatible with it. In Tear Strength Test, the highest of denim is in warp-5978 gm (type4), weft-6677 gm (type-2) and corduroys warp-5787 gm (type-2), weft-5578 gm (type-5). Denim has higher tear strength than corduroy because of the more GSM and the more Tear Strength. In the rubbing test, the corduroy garment has better colour fastness compared to the denim garment. In corduroy garment, the scale of the rubbing test is $4 / 5$ which is seen in both dry and wet form. In denim garments, the dry form has the highest scale of $4 / 5$ but wet has $2,2 / 3$ which shows low colour-fastness.

In all these results, corduroy garment is shown compared well with denim garment and achieving the required goals.

\section{Future Scope}

More information about the garment can be used for a better purpose.

It can be used for new fashionable garments.

Increasing usage and popularity can make for bulk production.

It can be affordable for all classes of people.

\section{Conflicts of Interest}

The authors declare no conflicts of interest regarding the publication of this paper.

\section{References}

[1] Ahmed, T., Mia, R. and Tanjim, M.J. (2020) An Extensive Analysis of the Health Hazards for RMG Workers in Apparel Sector of Bangladesh. Journal of Textile Engineering \& Fashion Technology, 6, 141-146.

[2] Mia, R., et al. (2019) Review on Various Types of Pollution Problem in Textile Dyeing \& Printing Industries of Bangladesh and Recommandation for Mitigation. Journal of Textile Engineering \& Fashion Technology, 5, 220-226. https://doi.org/10.15406/jteft.2019.05.00205

[3] Roy, B., et al. (2017) The Effect of Washing on the Performance Characteristics of Wideband Textile Microstrip Antennas. Advances in Wireless and Mobile Com- 
munications, 10, 1001-1006.

[4] Mia, R., Islam, M.A., Ahmed, B. and Mojumdar, J.I.A. (2017) Woolenization of Jute Fibre. European Scientific Journal, 13, 314-326. https://doi.org/10.19044/esj.2017.v13n30p314

[5] Dickerson, K.G. (2004) Inside the Fashion Business. Pearson Education India, Chennai.

[6] Baidya, K., et al. (2020) Study on Yarn Quality Variation from Spinning Position to Position in Ring Frame. IOSR Journal of Polymer and Textile Engineering, 7, 18-25.

[7] Al Mojnun Shamim, S.S., et al. (2019) Reuse of Standing Dye Bath of Reactive Dyeing with Nylon \& Silk. International Journal of Engineering Sciences \& Research Technology, 70, 5-30.

[8] Habib-A-Rasul, S.S. and Saleh, M.A. (2020) Statistical Analysis of Fiber Quality to Obtain a Correlation between the Fiber and Yarn Quality. Journal of Textile Engineering \& Fashion Technology, 6, 236-239.

[9] Gusakov, A.V., et al. (2000) Surface Hydrophobic Amino Acid Residues in Cellulase Molecules as a Structural Factor Responsible for Their High Denim-Washing Performance. Enzyme and Microbial Technology, 27, 664-671. https://doi.org/10.1016/S0141-0229(00)00264-7

[10] Delkumburewatte, G. and Madusanka, A. (2014) Impact of Selected Finishing Treatments on Strength Properties of Trouser Materials. Journal of Engineering and Technology of the Open University of Sri Lanka, 2, 27-42.

[11] Banna, B.U., et al. (2019) Effectiveness of Dyeing with Dye Extracted from Mango Leaves on Different Fabrics by Using Various Mordants. North American Academic Research, USA.

[12] Caiyuan, C.J. (1992) Tearing Failure Mechanism of Woven Fabrics and Comparison between Tear Test Methods.

[13] Mia, R., et al. (2020) The Fabrication of Composite Material Based on Natural Macromolecules: A Review. Open Access Library Journal, 7, e6977.

[14] Elahi, S., et al. (2019) Analysis of Physical \& Chemical Properties of Cotton-Jute Blended Denim after a Sustainable (Industrial Stone Enzyme) Wash. Journal of Textile Science and Fashion Technology, 3, 1-8.

[15] Sajib, M., Banna, B. and Mia, R. (2020) Mosquito Repellent Finishes on Textile Fabrics (Woven \& Knit) by Using Different Medicinal Natural Plants. Journal of Textile Engineering \& Fashion Technology, 6, 164-167.

[16] Rahman, M.M., et al. (2020) Synthesis and Investigation of Dyeing Properties of 8-Hydroxyquinoline-Based Azo Dyes. Journal of the Iranian Chemical Society, 1-10. https://doi.org/10.1007/s13738-020-02070-2

[17] Mia, R. and Sultana, S. (2020) Fabrication and Properties of Silver Nanowires (AgNWs) Functionalized Fabric. SN Applied Sciences, 2, Article No. 2052. https://doi.org/10.1007/s42452-020-03845-1

[18] Sultana, S., et al. (2019) Study on the Effects of Multilayered and Multi-Directional Stitched on the Ballistic Performance of Kevlar Fabric. North American Academic Research, USA.

[19] Tang, X., et al. (2018) Acoustical Analysis of Corduroy Fabric for Sound Absorption: Experiments and Simulations. Journal of Industrial Textiles, 48, 201-220. https://doi.org/10.1177/1528083717725912

[20] Luo, Y. (2018) The Wrinkled Hats. A Study on Sustainable Material of Washed Kraft Paper of Compression Hat Design. Politecnico, Milano. 